\title{
BLACK SEA COSSACK ARMY BETWEEN THE SOUTHERN BUG AND THE DNIESTER: HISTORIOGRAPHY OF THE ISSUE
}

\author{
Oleksandr Lozheshnyk \\ ORCID: https://orcid.org/0000-0002-4515-5511 \\ Post-graduate student of the Department of History of Ukraine \\ Odessa I.I. Mechnikov National University \\ 2, Dvoryanska Str., Odessa, 65082, Ukraine \\ sandro241298@ukr.net
}

The article analyzes the historiography of the Black Sea troops during their stay in the BugDniester interfluves, which objectively can be divided into three main periods, each of which is characterized by its own "vision" and interpretation of the history of the Black Sea troops. So, for example, if the first period is characterized by an ambiguous attitude to the Ukrainian Cossacks: the idealization changes to openly biased approaches, which completely deny any constructivism in their history; the third period is characterized by a burst of interest in the history of the Black Sea troops on the interfluve territory, the identification of new archival documents and rethinking of previously known facts. The diversity of research allows, by comparing information and comparing facts in the works of different authors, to objectively cover the history of the army during its stay in the Bugo-Dniester interfluves area.

By the beginning of the 20th century a certain tradition in the study of the history of the Black Sea troops was formed. Its main features were: the use of a narrow range of sources of official origin, absolutization of the role of the Russian Empire government in the history of the Black Sea troops. This is explained by the fact that a critical analysis of the government policy and activities of the local administration on the Cossacks was not possible for a number of objective reasons: the stay of this topic in the shadow of more topical historiographical problems, limited access to the source base.

After 1917 studies of the history of the Black Sea Cossacks were transferred to the level of local history studies and for ideological reasons almost never took place. The next stage in the studying of the history of the army is connected with the second half of the 20th century. Among the most striking works of this period are the studies of V. Golobutsky and A. Bachinsky.

Thanks to the use of archival materials, a significant part of which was first introduced into the scientific turnover A. Bachinsky enriched the factual basis of the history of the Black Sea Army Cossacks at that time, drawing attention to their relations with the Turkish Cossacks.

Thus, during the second half of the twentieth century, the scope of research on the history of the Black Sea Army during its settlement in the Bugo-Dniester interfluvial was significantly expanded, new sources were used to study the socio-economic aspects of the Cossacks' situation during that period.

So, investigating the stay of the Cossacks of the Black Sea troops on the territory of Bug-Dniester interfluves, historians passed a way from the scientific interest in the history of the south of Ukraine as a whole (in the first half of the XIX century) to the fundamental works on various aspects of social and economic history of irregular Cossack formation of the late XVIII century (at the end of the XX-at the beginning of the XXI century).

Key words: Historiography, Black sea Cossack army, the Southern Bug, the Dniester, settlement and economic development of the region. 
Олександр Ложешник ORCID: https://orcid.org/0000-0002-4515-5511

Аспірант кафедри історія України Одеського національного університету імені I.I. Мечникова Вул. Дворянська, 2, Одеса, 65082, Україна sandro241298@ukr.net

\section{ЧОРНОМОРСЬКЕ КОЗАЦЬКЕ ВІЙСЬКО В МЕЖИРІЧЧІ ПІВДЕННОГО БУГУ ТА ДНІСТРА: ІСТОРІОГРАФІЯ ПИТАННЯ}

В статті проаналізовано історіографію Чорноморського війська під час його перебування в Буго-Дністровському межиріччі. Головний наголос зроблено на висвітленні проблеми оселення та господарського освоєння краю. Виокремлено та синтезовано етапи розвитку, важливі напрямки історичних досліджень та їхні особливості, висвітлено стан сучасних історичних пошуків та вказано на їхні перспективи.

Ключові слова: історіографія, Чорноморське козаџьке військо, Буго-Дністровське межиріччя, оселення та господарське освоєння краю.

Останні десятиліття ознаменувалися значним піднесенням української історіографії у вивченні широкого кола проблем, присвячених історії Чорноморського війська під час його перебування в Буго-Дністровському межиріччі. Але, незважаючи на широке обговорення зазначених проблем на наукових конференціях та в пресі, на сторінках фахових часописів та збірників, перевидання вартісних праць попередників, підготовку й захист кандидатських дисертацій, появу цікавих монографій та узагальнюючих досліджень, все ще не вдалося комплексно систематизувати надбання вчених - істориків щодо Бузько-Дністровського періоду (1787-1791 рр.) Чорноморського війська.

Даний сумний факт пояснюється тим, що протягом багатьох років чимало істориків, досліджуючи козацтво, замовчували факти, які свідчили про перебування чорноморців на території Буго-Дністровського межиріччя. I це в той час, коли завдяки напрацюванням А. Скальковського цей регіон став своєрідним «першопрохідцем» у виокремленні наукового напрямку дослідження історії українського козацтва. До того ж саме в Одесі було вперше надруковано «Устное повествование бывшего запорожца Н. Л. Коржа», що й досі містить в собі неоціненні відомості із життя чорноморців, зокрема, ілюструючи їх перебування на території Хаджибею. Окрім того, починаючи з 1844 р. майже в кожному з 33 томів «Записок Одеського Імператорського товариства історії та старожитностей» друкувались матеріали та документи з історії українського козацтва.

Історіографію перебування козаків Чорноморського війська на території БугоДністровського межиріччя, заселення та економічного освоєння краю об'єктивно можна розділити на три основні періоди: перший період: XIX - початок XX ст., другий період: 1920-ті - 1990-ті рр., третій період: 1991 р. - початок XXI ст.

Кожен період характеризується своїм «баченням» та трактуванням історії Чорноморського війська. Так, наприклад, якщо для першого періоду властиве неоднозначне ставлення до українських козаків: ідеалізація змінюється відверто упередженими підходами, які повністю заперечують будь-який конструктивізм в їх історії; то для третього періоду властиві бурхливий сплеск інтересу до історії козаків Чорноморського війська на території межиріччя, виявлення нових архівних доку- 
ментів, переосмислення раніше відомих фактів. Різноплановість досліджень дає змогу, порівнюючи відомості та зіставляючи факти у працях різних авторів, об'єктивно висвітлювати історію війська під час його перебування в БугоДністровському межиріччі.

Початком вивчення історії Чорноморського війська в зазначений період стали праці А. Скальковського, який одним з перших почав займатися систематичним дослідженням історії Південної України загалом та Чорноморського війська в контексті вивчення Війська Запорозького. Проаналізувавши значну кількість документів Архіву Коша Війська Запорозького Низового та Канцелярії Новоросійського і Бессарабського генерал-губернатора, дослідник сформував своє бачення ролі козацтва в історії південноукраїнського регіону, яке відрізнялось від офіційної точки зору царського уряду, сформульованої в указі 1775 р. про знищення Запорозької Січі. А. Скальковський наголошував на тому, що «віднайдені запорозькі документи подають нам дипломатичне, церковне, військове, судове, торговельне, адміністративне і навіть приватне листування запорожців» [61, с. 4-5], що допомогло надати документальне підтвердження історії Чорноморського війська.

У дослідженні «Історія Нової Січі, або останнього Коша Запорозького» Аполлон Олександрович описав передумови створення та «зародження» Чорноморського війська, вказавши на перебування козаків на території сучасної Одещини, ще задовго до звільнення Очаківської області від турків в 1789 р.: «В Одесі збереглись перекази, що запорожці, які «зашуміли веслами до Тилігулу», там не всиділи, а оселились біля підніжжя Хаджибейської фортеці в так званій тепер Карантинній Балці» [60, с. 198].

Археографічні праці дослідника з історії козацтва не втрачають актуальності й сьогодні. Безперечною заслугою А. Скальковського є введення до наукового обігу нового фактологічного матеріалу щодо появи козаків у регіоні, їх оселення та господарського освоєння краю $[56$, с. $127 ; 58$, с. 276]; публікація документів, що стосувались Чорноморської козацької команди, зокрема переписів населення Одеси 1795 та 1797pp. [57, с. 45-46, 48-49, 61-62]. Деякі, хоча й досить уривчасті свідоцтва про Чорноморську команду містяться і в його статистичній праці «Хронологическое обозрение истории Новороссийского края» [59]. Але найбільша цінність напрацювань А. Скальковського в тому, що більшість оригіналів документів Коша Запорозького, які зберігалися в Державному архіві Одеської області, на жаль, в 1960-х рр. була втрачена.

Поряд із А. Скальковським працював з архівом Коша Яків Павлович Новицький. Протягом 1886-1898 рр. він вивчав джерела Архіву, що знайшло відображення в чисельних публікаціях. Для дослідження історії Чорноморського війська найцікавішими є дослідження «Описание границ и городов бывшей Азовской губернии, Левобережная часть нынешней Екатеринославской губернии 1775-1788 гг. Архивные источники» [41], що містить цінні відомості щодо заселення південного краю, дозволяє зрозуміти історичні передумови та пояснити соціально-економічні причини появи Чорноморського війська в останній чверті XVIII ст.; «История города Александровска Екатеринославской губернии в связи с историей возникновения крепостей Днепровской линии», де опубліковано список чорноморських козаків засновників Олександрівська. Заслуговують на увагу й додатки до розвідки, де вміщені документи різної видової належності 3 інформацією про перебування колишніх запорожців у складі Чорноморського війська [40, с. 50, 185, 210-263, 271-303].

У 1889-1910 рр. Я. Новицький опублікував різноманітні документи та замітки, що дозволяють простежити долі чорноморських козаків; дослідити родоводи козацької старшини та пояснити причини формування Чорноморського війська. 
Значення цих публікацій вкрай важливе, бо до сьогодні не дійшла більшість першоджерел, якими користувався дослідник. До того ж переважна частка оприлюднених Я.Новицьким документів була взята не 3 власних зібрань А. Скальковського чи інших дослідників, а з місцевих архівів.

Поряд 3 документальним матеріалом Я. Новицький у своїх розвідках використовував і усні джерела [40, с. 217, 322, 329]. Поєднання рукописного матеріалу з усними джерелами дозволило досліднику відтворити неповторні сторінки повсякденного життя чорноморців. Опрацьовані ним матеріали місцевих архівів та усні перекази старожилів, свідків пам'ятних подій стали канвою для написання низки історичних та статистичних праць. Поміж таких розвідок звертає на себе увагу праця «С берегов Днепра (Очерки Запорожья). Путевые записки и исследования», де Я. Новицький не тільки зафіксував розповіді 70-річного діда Миколи Білого - внука «війська Чорноморського полкового осавула» Федора Білого, а й навів витяги 3 документальних джерел, які зберігалися в родині Білих не одне покоління й були зафіксовані в справі про родовід Білих, що відклалася в Архіві предводителя дворянства Олександрійського повіту.

Доробок А. Скальковського став поштовхом у появі студій з розгляду історії Чорноморського війська в зазначений період. Починаючи 31883 р. козакознавчою тематикою займався Д. Яворницький. Протягом багатьох років дослідник мандрував теренами Катеринославської, Херсонської, Таврійської та Полтавської губерній, розшукуючи запорозькі (чорноморські) старожитності, записував від місцевих старожилів народні пісні, легенди, прислів'я про козацьку давнину. Згодом знайдені під час мандрівок та експедицій матеріали стали основою низки його краєзнавчих праць [71, 72]. Зокрема, в археографічній збірці «До історії Степової України» вчений опублікував документи, опрацьовані в архіві казенної палати Катеринослава, зосередивши увагу на заснуванні причорноморських міст i сіл у колишніх запорозьких вольностях.

Історико-краєзнавчі аспекти заявленої теми досліджували в ХІХ ст. О. Маркевич [37], В. Надлєр [38, 39], К. Смольянинов [61, 62], В. Бімбасов [3], розглядаючи розселення козаків Чорноморського війська в м. Одеса і його околицях та існування Чорноморської козацької команди. В цьому напрямкові проводили дослідження В. Яковлєв, вказавши «бывшие в ведении Черноморского войска селения»: Біляївку (Головківку), Калаглію, Кучургани, Глинне, Чобручі, Незавертай, Аджидер, Яськи, Ханкишл (Удобне), Рошу (Козацьке), Акерман, Коротне [73, 74]; О. Орлов, розповівши про долю чорноморців, що залишилися в Буго-Дністровському межиріччі після переселення основної частини війська на Кубань [23].

Окрім фактологічного матеріалу у своїх напрацюваннях історики використовували місцеві перекази, зазначаючи, що по селах та хуторах «Дальницької ділянки» «оселились залишки колись славного війська Запорозького». Цієї думки дотримувався й О. Де-Рібас, описуючи, як після розгрому Січі частина запорожців разом зі своїми родинами оселилась «де кому було дозволено, й багато з них опинилось під стінами Хаджибею» [15]. На жаль, цікаві подробиці життя чорноморців на околицях Хаджибею (Одеси) не мають фактологічних підтверджень [22, 63].

Оригінальними є дослідження П. Іванова, написані після експедиції по місцях, де мешкали нащадки козаків та опрацювання різнопланових архівних документів. Перебуваючи в 1901 p. у с. Слободзея, вчений ознайомився із матеріальними залишками перебування тут чорноморців та відвідав хату нащадка козаків, який відмовився переселитись на Кубань. У його працях вміщено подробиці, що 
стосуються господарства чорноморців та клопотів, пов'язаних 3 переселенням на Кубань [19, 20], опис предметів ритуального призначення і книжок, подарованих свого часу військовим суддею А. Головатим, купча на продаж А. Головатим свого хутору з будинком і млином 28 квітня 1793 р. купцеві С. Кленову [20, 21].

Продовжили дослідження процесів колонізації Півдня України та участі в господарському освоєнні краю козаків Чорноморського війська Д. Багалій [4] та В. Біднов $[6,7]$, подаючи цінний матеріал щодо специфіки заселення краю.

Окрему групу в історіографії зазначеної тематики становить «кубанська історіографічна школа», яку репрезентують кубанські науковці (переважно українського походження та вихідці з козацького середовища, що не могло не вплинути на загальні концепції їхніх досліджень) . У пошуках історичних витоків Чорноморського війська дослідниками було опрацьовано джерела ДАКК, що стосувались обставин виникнення іррегулярного формування та основних моментів його історії наприкінці XVIII ст., долі його окремих представників, насамперед кошових отаманів.

П. Короленко, використовуючи архівні документи ДАКК, описав процес трансформації решток колишнього запорозького суспільства у Чорноморське військо $[27,31,32,33]$ та написав біографії старшин - С. Білого, З. Чепіги й А. Головатого $[26,28,29,30]$. Щоправда, його праці вирізняються описовістю та фактографічністю у викладі матеріалу. Як представник офіційної дворянсько-монархічної ідеології, автор зображав козаків Чорноморського війська насамперед захисниками інтересів уряду Російської імперії.

Прорив у дослідженні Чорноморського війська здійснив Ф. Щербина [70], поклавши в основу досліджень архівні документи різної видової належності: актові, справочинні, статистичні. Поряд з ними, учений не останнє місце відводив мемуарним творам, у тому числі й епістолярії, в яких, на думку вченого, можна віднайти свідчення, які б характеризували побутові особливості козака, його світогляд.

Таким чином, до початку ХХ ст. утворилася певна традиція у дослідженні історії Чорноморського війська. Головними ії особливостями були: використання вузького кола джерел офіційного походження, абсолютизація ролі уряду Російської імперії в історії чорноморців. Це пояснюється тим, що критичний аналіз політики уряду та діяльності місцевої адміністрації щодо козаків був неможливим через низку об'єктивних причин: перебування зазначеної теми у тіні більш актуальних історіографічних проблем, обмеженість доступу до джерельної бази.

Після 1917 р. дослідження історії Чорноморського війська під час їх перебування в Буго-Дністровському межиріччі у зазначений період було переведено на рівень краєзнавчих досліджень та з ідеологічних причин майже не проводилося. Як виняток, слід назвати праці: Ф. Петруня [42, 43] (карта поселень Чорноморського війська, як і висновки вченого, на жаль, і досі залишаються неопублікованими); О. РябінінаСкляревського [44], написані на основі опрацювання архівних справ Державного архіву Одеської області; Є. Загоровського [16], який негативно оцінював факт переселення 3 Очаківської області чорноморців та вказував на те, що вони були нащадками запорожців, які примирилися 3 «новим порядком речей» після зруйнування Запорозької Січі.

Наступний етап вивчення історії війська пов'язаний з другою половиною ХХ ст. Серед найяскравіших праць цього періоду слід назвати дослідження В. Голобуцького $[8,9]$, що зосередив свою увагу головним чином на господарському устрої та соціально-економічних стосунках чорноморців, які розглядав через призму нескінченної класової боротьби в козацькій громаді. 
Велику увагу дослідженню соціально-економічних процесів Півдня України приділили у своїх працях В. Загоруйко [18] та В. Кабузан [24, 25]. Так, наприклад, В. Загоруйко назвав козацтво корінним населенням краю, а важливим доповненням до його книги стали примітки, що являють собою «словник» місцевої історії.

В 60-ті pp. ХX ст. історію Чорноморського війська (на основі матеріалів Державного архіву Одеської області та Державного архіву Краснодарського краю) почав досліджувати А. Бачинський. У співавторстві з О. Бачинською вченим була написана книга «Козацтво на Півдні України 1775-1869 рр.» [5], де на основі аналізу опублікованих та нововиявлених архівних документів усестороннє розглянуто основні моменти історії іррегулярного формування, особливості громадського та господарського життя козаків, пов'язані з Буго-Дністровським межиріччям.

Завдяки використанню архівних матеріалів, значна частина яких була вперше введена у науковий обіг, як і «Іменний список чорноморських старшин та козаків, які залишаються при місті Одесі» (1797р.), А. Бачинський збагатив фактологічну базу історії козаків Чорноморського війська в зазначений час, звернувши увагу на їх зв'язки з турецькими запорожцями.

Низку архівних документів, що дозволили скласти перепис населення Одеси 1799 р. та виокремити біля 300 родин чорноморців, які залишились після переселення на Кубань, використала в своїх дослідженнях О. Дружиніна, окресливши специфіку розвитку регіону та розкривши залежність колонізаційних процесів від особливостей господарського розвитку.

Таким чином, протягом другої половини XX ст. було значно розширено рамки досліджень 3 історії Чорноморського війська під час його поселення в БугоДністровському межиріччі, залучено нові джерела для дослідження соціальноекономічних аспектів становища козаків в зазначений період.

Наприкінці 1980 - на початку 1990 рр. поширюється загальногромадський інтерес до історії козацького руху в Україні. Значним чином це пояснюється тим, що в незалежній державі, у зв'язку зі зняттям цензурних політико-ідеологічних обмежень, почався процес переосмислення української історіографії, для якої, як i наприкінці минулого століття, козацтво залишалося уособленням славних сторінок вітчизняної історії. Так як Чорноморське військо вважається спадкоємцем та правонаступником Запорозької Січі в південноукраїнському регіоні, почалося відродження вивчення його історії на теренах південної України.

Серед цікавих напрацювань цього періоду слід назвати дослідження І. Анцупова $[1,2]$ та Р. Шияна [64, 65]. Зокрема, I. Анцупов детально розкрив загальні процеси колонізації Буго-Дністровського межиріччя козаками Чорноморського війська та історію формування аграрних відносин на Півдні України. Значна кількість архівних матеріалів дозволила автору грунтовно охарактеризувати картину соціального та економічного розвитку досліджуваної території.

Наприкінці XX ст. поновилися дослідження козацьких намогильних пам'ятників, завдяки яким збережено дослівні написи на хрестах козацьких поховань, зафіксовано їх точне місцезнаходження. Вивчаючи намогильні пам'ятники на околицях Одеси та в прилеглих селах (Куяльник, Усатове, Нерубайське тощо), Р. Шувалов навів цікаві факти про життя чорноморців в Буго-Дністровському межиріччі [66, 67, 68, 69]. На основі історичних матеріалів, серед яких були записи метричних книг місцевої Вознесенської церкви за 1809-1822 рр. та польових даних він довів факт проживання козаків Чорноморського війська на схилах Шкодової і Жевахової гір та їх поховання на Куяльницькому козацькому кладовищі. 
До вивчення намогильних козацьких пам'ятників з 1994 р. долучився I. Сапожніков [34, 49, 51, 53]. Слід зазначити, що окрім вивчення козацьких хрестів [46, 51], вчений плідно працює 3 матеріалами Держархів Одеської області, які висвітлюють історію Чорноморського війська під час його перебування на території Хаджибею (Одеси). На їх основі була написана низка праць [47, 50], серед яких вирізняються студії «Запорожские и черноморские казаки в Хаджибее и Одессе (1770-1820-е гг.)» [48] (спільно з Г. Сапожніковою), де розглянуто роль полкового осавула Ф. Черненка при оселенні козаків в околицях Хаджибею, після переселення чорноморців на Кубань в 1792-1793 рр.

Поряд із зазначеними працями 3 друку вийшли і продовжують виходити дослідження, які стосуються поставленої наукової проблеми. Серед них праці Т. Гончарука $[10,11,12,13,14]$ та С. Гуцалюка, I. Сапожнікова та Г. Сапожнікової $[45,48,52,54]$, А. Ложешник $[35,36]$, що торкаються низки козакознавчих питань щодо життя та діяльності чорноморців в зазначений період в Буго-Дністровському межиріччі.

Отже, досліджуючи перебування козаків Чорноморського війська на території Буго-Дністровського межиріччя, історики пройшли шлях від наукового інтересу до історії півдня України в цілому (в першій половині ХІХ ст.), до грунтовних праць щодо різних аспектів соціально-економічної історії іррегулярного козацького формування кінця XVIII ст. (наприкінці XX - на початку XXI ст.). Щодо характеру сучасних досліджень історії Чорноморського війська, то слід відзначити їх спрямування на «занурення» вглиб теми шляхом пошуку нових джерельних баз i постановки та розробки нових аспектів. Оприлюднення нових архівних документів та «перепрочитання» раніше опублікованих дає змогу широкому загалу розглянути різні аспекти історії чорноморців в Буго-Дністровському межиріччі.

\section{Джерела та література:}

1. Анцупов И. А. Казаки и военные поселенцы на Днестре и Буге XVIII-XIX веков / И. А. Анцупов // Ежегодный исторический альманах Приднестровья. - 1997. - № 1. - С. 3039.

2. Анцупов И. А. Казачество российское между Бугом и Дунаем. / И. А. Анцупов. Кишинев, 2000. - 290 с.

3. Архив графов Мордвиновых: в 10 т. / предисл. и прим. В. А. Бимбасова. - СПб.: Тип. И. Н. Скороходова, 1901. - Т. 1. - 713 с.

4. Багалей Д. И. Колонизация Новороссийского края и первые шаги его по пути культуры / Д. И. Багалей // Киевская старина, 1889. - Т. 41. - С. 351-360.

5. Бачинський А. Д. Козацтво на Півдні України 1775-1869 pp. / А. Д. Бачинський, О. А. Бачинська. - Одеса: Маяк, 1995. - 56 с.

6. Беднов В. А. К истории бывших запорожских старшин и казаков./ В. А. Беднов. Екатеринослав: Тип. губ. земства, 1915. - 47 с.

7. Беднов В. Материалы для истории колонизации бывших запорожских владений. / В. Беднов. - Екатеринославль: тип. Губернского земства, 1914. -48 с.

8. Голобуцкий В. А. Черноморское казачество./ В. А. Голобуцкий. - Киев: Академия наук УССР, 1956. - $416 \mathrm{c}$.

9. Голобуцький В. О. Чорноморське козацтво за Бугом: до питання про соціальноекономічний розвиток степової України наприкінці XVIII ст. / В. О. Голобуцький // Наукові Записки Інституту історії АН УРСР. -Київ, 1952. - Т. 4. - С. 133-154.

10. Гончарук Т. Г. Григорій Потьомкін - гетьман українського козацтва: наук.-популяр. нарис. / Т. Г. Гончарук. - Одеса : Астропринт, 2002. - 141 с. 
11. Гончарук Т. Г. История Хаджибея (Одессы). 1415-1795 гг. Одесса: Астропринт, 1997. $88 \mathrm{c}$.

12. Гончарук Т. Г. Історія Хаджибея (Одеси) 1415-1795 pp. в документах. / Т. Г. Гончарук. Одеса: Астропринт, 2000. - 372 с.

13. Гончарук Т. Г. Нащадки українських козаків та «народження Одеси». / Т. Г. Гончарук. Одеса: Астропринт, 2006. - 144 с.

14. Гончарук Т. Г. Українське козацтво та Хаджибей (Одеса). Середина XVI ст. 1794 р.: популярний нарис та додані документи з друкованих джерел./ Т. Г. Гончарук, С. Гуцалюк. -. Одеса, 1998. - 67 с.

15. Де-Рибас А. Старая Одесса: исторические очерки и воспоминания. / А. Де-Рибас. Одесса: Тип Южнорус. о-ва печати, 1913. - 51 с.

16. Загоровский Е. А. Деятельность П. А. Зубова по управлению степной Украиной / Е. А. Загоровский // Вісник Одеської комісії краєзнавства. - 1929. - № 4-5. - С. 44-58.

17. Загоровский Е. А. Матеріали до історії адміністративного устрою південної України: (друга половина XVIII - перша половина XIX століття)./ / Е. А. Загоровский. - 1999. C.492-506.

18. Загоруйко В. А. По страницам истории Одессы и Одесщины: историографический и библиографический обзор./ В. А. Загоруйко. - Одесса, 1957. - Вып. 1. - 155 с.

19. Иванов П. А. Материалы по истории Запорожья в XVIII в. / П. А. Иванов // ЗООИД. Одесса,1897. - Т. 20. - С. 59-100.

20. Иванов П. А. Черноморские казаки в Слободзее / П. А.Иванов // ЗООИД. - 1902. - Т. 24. - С. 80-91.

21. Иванов П. К истории запорожских казаков после уничтожения Сечи / П. А.Иванов // ЗООИД. - 1904. - T. 25. - С. 20-40.

22. Из прошлого Одессы : сб. ст. / сост. Л. М. Де-Рибас. - Одесса: изд. Г. Г. Маразли, 1894. $413 \mathrm{c}$.

23. Исторический очерк Одессы с 1794 по 1803 год / сост. А. Орлов. - Одесса: тип. Шульце, 1885. $-144 \mathrm{c}$.

24. Кабузан В. М. Заселение Новороссии (Екатеринославская и Херсонская губернии) в XVIII первой половине XIX в. (1719-1858 гг.) / В. М. Кабузан; отв. ред. Л. Г. Бескровный. - М.: Наука, 1976. - 306 c.

25. Кабузан В. М. Народонаселение Бессарабской области и Левобережных районов Приднестровья, конец XVIII - первая половина XIX в. / В. М. Кабузан . - Кишинев: Штиинца, 1974. - 157 c.

26. Короленко П. П. Головатый - кошевой атаман Черноморского казачьего войска. /

П. П. Короленко. - Екатеринодар: Тип. Кубан. обл. правл., 1904. - 201 с.

27. Короленко П. П. Двухсотлетие Кубанского казачьего войска: ист. очерк. / П. П. Короленко. Екатеринодар: Тип. Кубанского обл. правления, 1896. - 96 с.

28. Короленко П. П. Кошевые атаманы Черноморского казачьего войска XVIII ст.: историкобиографический очерк. / П. П. Короленко. - СПб.: Вестник казачьих войск, 1896. - 48 с.

29. Короленко П. П. Первые четыре атамана бывшего Черноморского (ныне Кубанского) казачьего войска. / П. П. Короленко. - Екатеринодар, 1892. - 36 с.

30.Короленко П. П. Письмо Н. Т. Белого к П. П. Короленко о Сидоре Белом / П. П. Короленко. // ЗООИД.-1898. - Т. 21. - С. 46-56.

31. Короленко П. П. Предки кубанских казаков на Днепре и на Днестре. / П. П. Короленко. Екатеринодар: Тип. П. Ф. Бойко, 1900. -203 с.

32. Короленко П. П. Черноморское казачье войско (1775 - 1792): ист. очерк. / П. П. Короленко. Екатеринодар: Типо-литогр. А. В. Сташевского, 1892. - 64 с.

33. Короленко П. П. Черноморцы. / П. П. Короленко. - СПб.: Тип. Департамента уделов, 1874. $272 \mathrm{c}$. 
34. Кушнір В. Г. Попередні підсумки досліджень кам'яних хрестів Одещини / В. Г. Кушнір, I. В. Сапожников // Українська національна ідея: минуле, сучасне, майбутнє: матеріали міжнародної конференції. - Одеса. 1995. - С. 120-121.

35. Ложешник А. С. Старшина козацьких військ на Півдні України (кінець XVIII - перша половина XIX ст.): просопографічний портрет: дис ... канд. іст. наук. / А. С. Ложешник- Одеса, 2017. $-239 \mathrm{c}$.

36. Ложешник А. Формулярні списки старшини Чорноморського козацького війська за 1804 р., як історичне джерело / А. Ложешник // Чорноморська минувшина. - Одеса: СПД -ФО Бровкін О. В., 2013. - Вип. 8. - С. 174-188.

37. Маркевич А. И. Документы, относящиеся к истории города Одессы / А. И. Маркевич // ЗООИД. - 1893. - Т. 16. - С. 55-116

38. Надлер В. К. К изучению истории г. / В. К. Надлер. - Одессы. - Одесса, 1893. - 11 с.

39. Надлер В. К. Одесса в первые эпохи ее существования. / В. К. Надлер. - Одесса: Тип. В. В. Кирхнера, 1893. - 100 с.

40. Новицкий Я. Твори в 5-ти томах. Т. 1: История города Александровска Екатеринославской губернии в связи с историей возникновения крепостей Днепровской линии. 1770 - 1806 гг. / Я. Новицкий. - Запоріжжя: ПП «АА Тандем», 2007. - 508 с.

41. Новицкий Я. П. Описание границ и городов бывшей Азовской губернии (Левобережная часть нынешней Екатеринославской губернии) (1775- 1783 гг.). / Я. Новицкий. - Александровск, 1910. $-38 \mathrm{c}$.

42. Петрунь Ф. Е. Первые русские карты окрестностей нынешней Одессы и их физикогеографическое содержание / Ф. Е. Петрунь // Тр. Одес. гос. ун-та. - 1955. - Т. 145, вып. 3: Геол. и географ. науки. - С. 141-149.

43. Петрунь Ф. Е. Пути и подступы к Днестру: очерки по истории русской географии 2-й половины XVIII ст.: автореф. дис. ... канд. географ. наук. / Ф. Е. Петрунь . - Байрам-Али, 1944. $283 \mathrm{c}$.

44. Рябінін-Скляревський О. О. 3 життя Задунайської Січі / О. О. Рябінін-Скляревський // Україна. -1929. - Т. 34. - С. 7-34.

45. Сапожников И. В. Каменные кресты предместий Одессы: конец XVIII - XIX вв. / И. В. Сапожников. - Ильичевск: Элтон-2: Гратек, 1999. - 98 с.

46. Сапожников И. В. Намогильные памятники населения степей Нижнего Приднестровья (конец XVIII - первая половина XIX вв.). / И. В. Сапожников. - Одесса: Черноморье, 1997. - 134 с.

47. Сапожников И. В. Описание Одессы и Северного Причерноморья 1780-х годов: к 210-й годовщине штурма Хаджибейского замка. / И. В. Сапожников. - Ильичевск: Элтон-2 - Гратек, 1999. - $80 \mathrm{c}$.

48. Сапожников И. В. Запорожские и черноморские казаки в Хаджибее и Одессе (1770-1820-е гг.). / И. В.Сапожников, Г. В. Сапожникова. - Одесса: ОКФА, 1998. - 273 с.

49. Сапожников И. В. Основные итоги исследования православного кладбища Аккермана / И. В. Сапожников, Ю. А. Слюсарь // Древнее Причерноморье. - Одесса, 1996. - С. 97-100.

50. Сапожников I. В. Запорозькі та чорноморські козаки в Хаджибеї та Одесі / I. В. Сапожников // Київська. старовина. - Київ, 1998. - №3. - С. 11-25.

51. Сапожников I. В. Кам'яні хрести Степової України (XVIII - перша половина XIX ст.). / I. В. Сапожников. - Одеса: Чорномор'я, 1997. - 165 с.

52. Сапожников I. Чорноморська козацька команда в Хаджибеї та Одесі (1794-1797 роки) / І.Сапожников, Г. Сапожникова // Хаджибей-Одеса та українське козацтво (1415-1797 роки). Одеса: ОКФА, 1999. - С. 237-290.

53. Сапожников I. Типологія кам'яних намогильних хрестів Південно-Західної України / І. Сапожников, Ю. Слюсар, Р. Шувалов // Старожитності Причорномор'я. - Одеса. 1995. - Вип. 2. - C. $16-47$.

54. Сапожніков I. В. Штурм острова Березань чорноморськими козаками. / I. В. Сапожніков. Київ; Іллічівськ: Елтон 2; Гротек, 2000. - 128 с. 
55. Сапожніков I. В. Кам'яні хрести Одещини (з матеріалів розвідок) / І. В. Сапожніков, В. Г. Кушнір, А. С. Островерхов // Старожитності Причорномор'я. -Одеса, 1995. - Вип. 2. - С. 48-63.

56. Скальковский А. А. Опыт статистического описания Новороссийского края и Бессарабии. / А. А. Скальковский. - Одесса : Тип. Л. Нитче, 1850. - 386 с.

57.Скальковский А. А. Первое тридцатилетие истории города Одессы, 1793-1823. / А. А. Скальковский. - Одесса: Гор. тип., 1837. -296 с.

58. Скальковский А. А. Сравнительный взгляд на Очаковскую область в 1790 и 1840 гг. / А. А. Скальковский // ЗООИД. - Одесса, 1844. - Т. 1. - С. 257-277.

59. Скальковский А. А. Хронологическое обозрение истории Новороссийского края. / А. А. Скальковский. - Одесса: Гор. тип., 1838. - Ч. 2. - 349 с.

60. Скальковський А. О. Історія Нової Січі, або останнього Коша Запорозького. / А. О. Скальковський. - Дніпропетровськ: Січ, 1994. - 678 с.

61. Смольянинов К. История г. Одессы./ К. Смольянинов. - Одесса: Гор. Тип., 1853. - 284 с.

62. Смольянинов К. История Одессы . / К. Смольянинов // ЗООИД. - 1852. - Т. 3. - С. 338-432.

63. Старая Одесса: Взятие Хаджибея, основание Одессы, первый крестный ход 22 августа 1849 г. // Одесский листок. - 1909. - 22 августа

64.Шиян Р. I. Козацтво Південної України останньої чверті XVIII століття. / Р. I. Шиян. - Запоріжжя: Тандем-У, 1998. - 98 с.

65. Шиян Р. I. Чорноморське військо вірних козаків в останній чверті XVIII ст. / Р. I. Шиян. Запоріжжя: Тандем-У, 1996. - 28 с.

66. Шувалов Р. А. Казацкий Кош в окрестностях Одессы / Р. А. Шувалов // Археологічні дослідження пам'яток українського козацтва. - Київ, 1993. - Вип. 2. - С. 104-109.

67. Шувалов Р. А. Про що розповів некрополь (Куяльницьке козацьке кладовище міста Одеси). / Р. А. Шувалов. - Київ, 1992. - 125 с.

68. Шувалов Р. А. Украинские поселения в окрестностях Одессы / Р. А. Шувалов // Історичне краєзнавство Одещини. - Одеса, 1993. - Вип. 4. - С. 41-45.

69. Шувалов Р. Козацьке кладовище / Р. Шувалов // Пам’ятки України. - Київ, 1993. - №1/6. C. $180-181$.

70. Щербина Ф. А. История Кубанского казачьего войска. / Ф. А. Щербина. - Екатеринодар: Тип. Кубанского Областного Правления, 1910. - 746 с.

71.Яворницький Д. І. До історії степової України./ Д. І. Яворницький. - Дніпропетровськ: Січ, 2004. $443 \mathrm{c}$.

72. Яворницький Д. І. Запоріжжя в залишках старовини і переказах народу./ Д. І. Яворницький. Київ: Веселка, 1995. - 300 с.

73. Яковлев В. А. К истории заселения Хаджибея (1789 - 1795 гг.)./ В. А Яковлев. - Одесса, 1889. $-56 \mathrm{c}$.

74. Яковлев В. Из Одесской старины. Раздача земель в Гаджибее и его окрестностях. 1792-1794 /

В. Яковлев // Одесский вестник. - 1889. - 21 августа.

\section{References:}

1. Antsupov, I. A., 1997. Kazaki i voennye poselentsy na Dnestre i Buge XVIII-XIX vekov. Yezhegodnyy istoricheskiy almanakh Pridnestrovya, Vyp. 1, s. 30-39. [in Russian]

2. Antsupov, I. A., 2000. Kazachestvo rossiyskoe mezhdu Bugom i Dunaem. Kishinev. [in Russian].

3. Arkhiv grafov Mordvinovykh, 1901. Vol. 1. Sankt-Peterburg. [in Russian].

4. Bagaley, D. I., 1889. Kolonizatsiya Novorossiyskogo kraya i pervye shagi ego po puti kultury. Kievskaya starina, Vol. 41, s. 351-360. [in Russian].

5. Bachinskiy, A. D. \& Bachinska, O. A., 1995. Kozatstvo na Pivdni Ukrä̈ni 1775-1869 rr.. Odesa. [in Ukrainian].

6. Bednov,V. A., 1915. K istorii byvshikh zaporozhskikh starshin i kazakov. Yekaterinoslav. [in Russian].

7. Bednov, V., 1914. Materialy dlya istorii kolonizatsii byvshikh zaporozhskikh vladeniy.

Yekaterinoslavl. [in Russian].

8. Golobutskiy, V. A., 1956. Chernomorskoe kazachestvo. Kiev. [in Ukrainian]. 
9. Holobutskyi, V. O., 1952. Chornomorske kozatstvo za Buhom: do pytannia pro sotsialnoekonomichnyi rozvytok stepovoi Ukrainy naprykintsi XVIII st. Naukovi Zapysky Instytutu istorii AN URSR, Vol. 4, pp. 133-154. [in Ukrainian].

10. Honcharuk, T. H., 2002. Hryhorii Potomkin - hetman ukrainskoho kozatstva. Odesa. [in Ukrainian].

11. Goncharuk, T. G., 1997. Istoriya Khadzhibeya (Odessy). 1415-1795 gg. Odessa. [in Ukrainian].

12. Honcharuk, T. H., 2000. Istoriia Khadzhybeia (Odesy) 1415-1795 rr. v dokumentakh. Odesa. [in Ukrainian].

13. Honcharuk, T. H., 2006. Nashchadky ukrainskykh kozakiv ta «narodzhennia Odesy». Odesa. [in Ukrainian].

14. Honcharuk, T. H. \& Hutsaliuk, S., 1998. Ukrainske kozatstvo ta Khadzhybei (Odesa). Seredyna XVI st. - 1794 r.: populiarnyi narys ta dodani dokumenty z drukovanykh dzherel. Odesa. [in Ukrainian].

15. De-Ribas, A., 1913. Staraya Odessa: istoricheskie ocherki $i$ vospominaniya. Odessa. [in Russian].

16. Zagorovskiy, Ye. A., 1929. Deyatelnost P. A. Zubova po upravleniyu stepnoy Ukrainoy. Visnik Odeskoï komisii kraieznavstva,4-5, s. 44-58. [in Ukrainian].

17. Zahorovskyi, E. A., 1999. Materialy do istorii administratyvnoho ustroiu pivdennoi Ukrainy: (druha polovyna XVIII - persha polovyna XIX stolittia), s. 492-506. [in Ukrainian].

18. Zagoruyko, V. A., 1957. Po stranitsam istorii Odessy $i$ Odesshchiny: istoriograficheskiy $i$ bibliograficheskiy obzor, Vol. 1. Odessa.[in Ukrainian].

19. Ivanov, P. A., 1897. Materialy po istorii Zaporozhya v XVIII v. ZOOID, 20, pp. 59-100. [in Russian].

20. Ivanov, P. A., 1902. Chernomorskie kazaki v Slobodzee. ZOOID, 24, pp. 80-91. [in Russian].

21. Ivanov, P., 1904. K istorii zaporozhskikh kazakov posle unichtozheniya Sechi. ZOOID, 25, pp. 20-40. [in Russian].

22. Iz proshlogo Odessy, 1894. Odessa. [in Russian].

23. Istoricheskiy ocherk Odessy s 1794 po 1803 god, 1885. Odessa. [in Russian].

24. Kabuzan, V. M., 1976. Zaselenie Novorossii (Yekaterinoslavskaya i Khersonskaya gubernii) $v$ XVIII - pervoy polovine XIX v. (1719-1858 gg.). Mykolaiv. [in Ukrainian].

25. Kabuzan, V. M., 1974. Narodonaselenie Bessarabskoy oblasti $i$ levoberezhnykh rayonov Pridnestrovya, konets XVIII - pervaya polovina XIX v. Kishinev. [in Russian].

26. Korolenko, P. P., 1904. Golovatyy - koshevoy ataman Chernomorskogo kazachego voyska. Yekaterinodar. [in Russian].

27. Korolenko, P. P., 1896. Dvukhsotletie Kubanskogo kazachego voyska. Yekaterinodar. [in Russian].

28. Korolenko, P. P., 1896. Koshevye atamany Chernomorskogo kazachego voyska XVIII st.: istoriko-biograficheskiy ocherk. Sankt-Peterburg. [in Russian].

29. Korolenko, P. P., 1892. Pervye chetyre atamana byvshego Chernomorskogo (nyne Kubanskogo) kazachego voyska. Yekaterinodar. [in Russian].

30. Korolenko, P. P., 1898. Pismo N. T. Belogo k P. P. Korolenko o Sidore Belom. ZOOID, 21, pp. 46-56. [in Russian].

31. Korolenko, P. P., 1900. Predki kubanskikh kazakov na Dnepre i na Dnestre. Yekaterinodar. [in Russian].

32. Korolenko, P. P., 1892. Chernomorskoe kazache voysko (1775-1792). Yekaterinodar. [in Russian].

33. Korolenko, P. P., 1874. Chernomortsy. Sankt-Peterburg. [in Russian].

34. Kushnir, V. H. \& Sapozhnykov, I. V., 1995. Poperedni pidsumky doslidzhen kam'ianykh khrestiv Odeshchyny. Ukrainska natsionalna ideia: mynule, suchasne, maibutnie: materialy mizhnarodnoi konferentsii. Odesa. S. 120-121. [in Ukrainian].

35. Lozheshnyk, A. S., 2017. Starshyna kozatskykh viisk na Pivdni Ukrainy (kinets XVIII - persha polovyna XIX st.): prosopohrafichnyi portret. Odesa. [in Ukrainian].

36. Lozheshnyk, A., 2013. Formuliarni spysky starshyny Chornomorskoho kozatskoho viiska za 1804 r., yak istorychne dzherelo. Chornomorska mynuvshyna, 8, pp. 174-188. [in Ukrainian].

37. Markevich, A. I., 1893. Dokumenty, otnosyashchiesya k istorii goroda Odessy. ZOOID, 16, pp. 55-116. [in Russian]. 
38. Nadler, V. K., 1893. K izucheniyu istorii g. Odessy. Odessa. [in Russian].

39. Nadler, V. K., 1893. Odessa v pervye epokhi ee sushchestvovaniya. Odessa. [in Russian].

40. Novitskiy, Ya., 2007. Istoriya goroda Aleksandrovska Yekaterinoslavskoy gubernii v svyazi s istoriey vozniknoveniya krepostey Dneprovskoy linii. 1770 - 1806 gg. Vol. 1. Zaporizhzhya. [in Ukrainian].

41. Novitskiy, Ya. P., 1910. Opisanie granits $i$ gorodov byvshey Azovskoy gubernii (Levoberezhnaya chast nyneshney Yekaterinoslavskoy gubernii) (1775- 1783 gg.). Aleksandrovsk. [in Russian].

42. Petrun, F. Ye., 1955. Pervye russkie karty okrestnostey nyneshney Odessy i ikh fizikogeograficheskoe soderzhanie. Trudy Odesskogo gosudarstvennogo universiteta, 145 (3), pp. 141149. [in Ukrainian].

43. Petrun, F. Ye., 1944. Puti i podstupy k Dnestru: ocherki po istorii russkoy geografii 2-y poloviny XVIII st. Bayram-Ali. [in Russian].

44. Riabinin-Skliarevskyi, O. O., 1929. Z zhyttia Zadunaiskoi Sichi. Ukraina, 34, pp. 7-34. [in Ukrainian].

45. Sapozhnikov, I. V., 1999. Kamennye kresty predmestiy Odessy: konets XVIII - XIX vv. Ilichevsk. [in Ukrainian].

46. Sapozhnikov, I. V., 1997. Namogilnye pamyatniki naseleniya stepey Nizhnego Pridnestrovya (konets XVIII - pervaya polovina XIX vv.). Odessa. [in Ukrainian].

47. Sapozhnikov, I. V., 1999. Opisanie Odessy i Severnogo Prichernomorya 1780-kh godov: $k$ 210y godovshchine shturma Khadzhibeyskogo zamka. Ilichevsk. [in Ukrainian].

48. Sapozhnikov, I. V. \& Sapozhnikova, G. V., 1998. Zaporozhskie i chernomorskie kazaki $v$ Khadzhibee i Odesse (1770-1820-e gg.). Odessa. [in Ukrainian].

49. Sapozhnikov, I. V. \& Slyusar, Yu. A., 1996. Osnovnye itogi issledovaniya pravoslavnogo kladbishcha Akkermana. Drevnee Prichernomore, pp. 97-100. [in Ukrainian].

50. Sapozhnykov, I. V., 1998. Zaporozki ta chornomorski kozaky v Khadzhybei ta Odesi. Kyivska starovyna, 3, pp. 11-25. [in Ukrainian].

51. Sapozhnykov, I. V., 1997. Kamiani khresty Stepovoi Ukrainy (XVIII - persha polovyna XIX st.). Odesa. [in Ukrainian].

52. Sapozhnykov, I. \& Sapozhnykova, H., 1999. Chornomorska kozatska komanda v Khadzhybei ta Odesi (1794-1797 roky). Khadzhybei-Odesa ta ukrainske kozatstvo (1415-1797 roky), pp. 237-290. [in Ukrainian].

53. Sapozhnykov, I., Sliusar, Yu. \& Shuvalov, R., 1995. Typolohiia kamianykh namohylnykh khrestiv Pivdenno-Zakhidnoi Ukrainy. Starozhytnosti Prychornomoria, 2, pp. 16-47. [in Ukrainian].

54. Sapozhnikov, I. V., 2000. Shturm ostrova Berezan chornomorskymy kozakamy. Kyiv-Illichivsk. [in Ukrainian].

55. Sapozhnikov, I. V., Kushnir, V. H. \& Ostroverkhov A. S., 1995. Kamiani khresty Odeshchyny (z materialiv rozvidok). Starozhytnosti Prychornomoria, 2, pp. 48-63. [in Ukrainian].

56. Skalkovskiy, A. A., 1850. Opyt statisticheskogo opisaniya Novorossiyskogo kraya i Bessarabii. Odessa. [in Russian].

57. Skalkovskiy, A. A., 1837. Pervoe tridtsatiletie istorii goroda Odessy, 1793-1823. Odessa. [in Russian].

58. Skalkovskiy, A. A., 1844. Sravnitelnyy vzglyad na Ochakovskuyu oblast v 1790 i 1840 gg. ZOOID, 1, pp. 257-277. [in Russian].

59.Skalkovskiy, A. A., 1838. Khronologicheskoe obozrenie istorii Novorossiyskogo kraya. Ch. 2. Odessa. [in Russian].

60. Skalkovskyi, A. O., 1994. Istoriia Novoi Sichi, abo ostannoho Kosha Zaporozkoho. Dnipropetrovsk. [in Ukrainian].

61. Smolyaninov, K., 1853. Istoriya g. Odessy. Odessa. [in Russian].

62. Smolyaninov, K., 1852. Istoriya Odessy. ZOOID, 3, pp. 338-432. [in Russian].

63. Staraya Odessa: Vzyatie Khadzhibeya, osnovanie Odessy, pervyy krestnyy khod 22 avgusta 1849 g., 1909. Odesskiy listok, 22 avgusta. [in Russian]. 
64. Shyian, R. I., 1998. Kozatstvo Pivdennoi Ukrainy ostannoi chverti XVIII stolittia. Zaporizhzhia. [in Ukrainian].

65. Shyian, R. I., 1996. Chornomorske viisko virnykh kozakiv v ostannii chverti XVIII st. Zaporizhzhia. [in Ukrainian].

66. Shuvalov, R. A., 1993. Kazatskyi Kosh v okrestnostiakh Odessy. Arkheolohichni doslidzhennia pam'iatok ukrainskoho kozatstva, 2, pp. 104-109. [in Ukrainian].

67. Shuvalov, R. A., 1992. Pro shcho rozpoviv nekropol (Kuialnytske kozatske kladovyshche mista Odesy). Kyiv. [in Ukrainian].

68. Shuvalov, R. A., 1993. Ukraynskye poselenyia v okrestnostiakh Odessy. Istorychne kraieznavstvo Odeshchyny, 4, pp. 41-45. [in Ukrainian].

69. Shuvalov, R., 1993. Kozatske kladovyshche. Pam'iatky Ukrainy, 1/6, pp. 180-181. [in Ukrainian].

70. Shcherbina, F. A., 1910. Istoriya Kubanskogo kazachego voyska. Yekaterinodar. [in Russian].

71. Yavornytskyi, D. I., 2004. Do istorii stepovoi Ukrainy. Dnipropetrovsk. [in Ukrainian].

72. Yavornytskyi, D. I., 1995. Zaporizhzhia $v$ zalyshkakh starovyny i perekazakh narodu. Kyiv. [in Ukrainian].

73. Yakovlev, V. A., 1889. K istorii zaseleniya Khadzhibeya (1789-1795 gg.). Odessa. [in Russian].

74. Yakovlev, V., 1889. Iz Odesskoy stariny. Razdacha zemel v Gadzhibee i ego okrestnostyakh. 1792-1794. Odesskiy vestnik, 21 avgusta. [in Russian].

Отримано: 04.12.2020 p. 